\title{
Distribution of Hemiphyllodactylus aurantiacus (Beddome, 1870) (Reptilia: Gekkonidae) in Andhra Pradesh, India
}

\author{
S.M. Maqsood Javed ${ }^{1}$, K. Thulsi Rao ${ }^{2}$, C. Srinivasulu ${ }^{3} \&$ Farida Tampal ${ }^{4}$ \\ ${ }^{1,4}$ World Wide Fund for Nature-India (WWF), APSO, 818, Castle Hills, Road No. 2, Near NMDC, Vijayanagar Colony, Hyderabad, Andhra \\ Pradesh 500057, India \\ ${ }^{2}$ Eco-Research and Monitoring Laboratories, Nagarjunasagar Srisailam Tiger Reserve, Sundipenta, Kurnool District, Andhra Pradesh \\ 518102, India \\ ${ }^{3}$ Wildlife Biology Section, Department of Zoology, University College of Science, Osmania University, Hyderabad, Andhra Pradesh 500007, India \\ Email: ${ }^{1}$ javedwwf2007@gmail.com
}

Date of publication (online): 26 January 2010 Date of publication (print): 26 January 2010 ISSN $0974-7907$ (online) | 0974-7893 (print)

Editor: Aaron Bauer

Manuscript details:

Ms \# 02312

Received 15 September 2009

Final received 24 September 2009

Finally accepted 28 December 2009

Citation: Javed, S.M.M., K.T. Rao, C. Srinivasulu \& F. Tampal (2010). Distribution of Hemiphyllodactylus aurantiacus (Beddome, 1870) (Reptilia: Gekkonidae) in Andhra Pradesh, India. Journal of Threatened Taxa 2(1): 639-643.

Copyright: (C) S.M. Maqsood Javed, K. Thulsi Rao, C. Srinivasulu \& Farida Tampal 2010. Creative Commons Attribution 3.0 Unported License. JoTT allows unrestricted use of this article in any medium for non-profit purposes, reproduction and distribution by providing adequate credit to the authors and the source of publication.

Author Details: See end of this article.

Author Contribution: SMMJ and KTR conducted the field surveys; SMMJ and CS identified and took measurements of the specimens; SMMJ, KTR, CS and FT equally contributed in writing this article.

Acknowledgements: See end of this article.
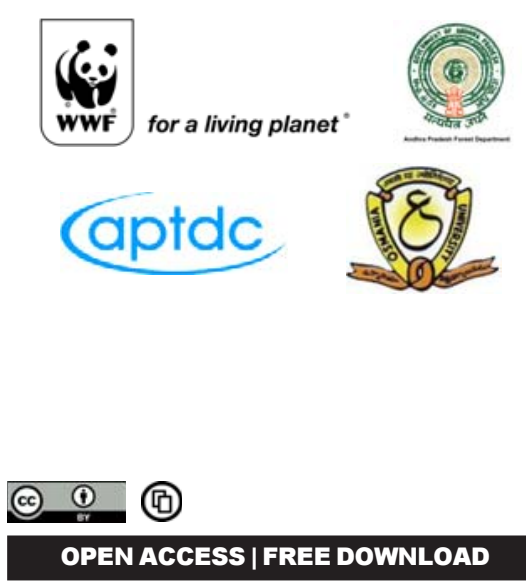

Abstract: A recent herpetofaunal survey in Andhra Pradesh resulted in many noteworthy findings. We report new localities of Hemiphyllodactylus aurantiacus (Beddome, 1870) on the basis of collected specimens, sightings and literature records. We present the current distribution of this endemic gecko in Andhra Pradesh, southern India and add morphometric, meristic and natural history notes.

Keywords: Andhra Pradesh, distribution, Hemiphyllodactylus aurantiacus, range extension, Southern Indian Half Leaf-fingered Gecko.

\section{INTRODUCTION}

The genus Hemiphyllodactylus Bleeker, 1880 remains one of the most poorly known genera of geckos (Bauer \& Das 1999). It is widespread and distributed from Sri Lanka to South China and the Japanese Ryukyu Islands, also inhabiting the Philippines, the Indo-Australian Archipelago, and some Islands of the Pacific Ocean (Bauer \& Das 1999; Malkmus et al. 2002). It is globally represented by only four species, namely, Hemiphyllodactylus aurantiacus (Beddome, 1870), Hemiphyllodactylus larutensis Boulenger, 1900, Hemiphyllodactylus typus Bleeker, 1860 and Hemiphyllodactylus yunnanensis Boulenger, 1903. In India, the genus Hemiphyllodactylus is represented by only two species, namely, Hemiphyllodactylus aurantiacus (Beddome, 1870) from mainland India (Smith 1935; Sanyal et al. 1993; Daniels 1994; Daniels \& Kumar 1998; Bauer \& Das 1999; Sharma 2002; Das 2002) and Hemiphyllodactylus typus Bleeker, 1860 from Andaman Islands (Das 2002). So far, Hemiphyllodactylus aurantiacus (Beddome, 1870), the Southern Indian Half Leaf-fingered Gecko, has been reported only from few locations in southern Indian states like Andhra Pradesh, Karnataka and Tamil Nadu (Smith 1935; Sanyal et al. 1993; Daniels 1994; Daniels \& Kumar 1998; Bauer \& Das 1999; Sharma 2002; Das 2002). Recent herpetological surveys have revealed the presence of this species from other localities in Andhra Pradesh. We report range extension of this gecko on the basis of collected specimens, sightings and literature records from northern and central Eastern Ghats. We also assess the current distribution and status of this endemic gecko of southern India in Andhra Pradesh, along with additional information on its habits and habitat.

\section{Materials and Methods}

Two specimens of Hemiphyllodactylus aurantiacus (Beddome, 1870) were collected from the wall of a canteen in a hotel in Araku Town on 28 February 2009, around $2000 \mathrm{hr}\left(18^{\circ} 50^{\prime} \mathrm{N} \& 79^{\circ} 42^{\prime} \mathrm{E}\right)$, Visakhapatnam District. A single specimen was captured, examined and released on 15 July 2009 around $1300 \mathrm{hr}$ by SMMJ from the forest guest house, Maredumilly, West Godavari District, Andhra Pradesh. On 20 August 2009, around $2200 \mathrm{hr}$ this species was recorded by KTR near Temple Locality $\left(15^{\circ} 36^{\prime} \mathrm{N}\right.$ \& $78^{\circ} 49^{\prime} \mathrm{E}$ ) in Gundla Brahmeswaram Metta (GBM) Wildlife Sanctuary, Prakasham District, Andhra Pradesh. Altogether 10 specimens were studied, of which only two were collected and the rest of them examined, photographed and released.

One male and one female specimen were euthanized, fixed in $10 \%$ formalin, preserved in $70 \%$ alcohol and deposited in the collection of the Zoological Survey of India, Fresh-water Biology Station, Vertebrate section (ZSI/FBS/V), Hyderabad. A photo voucher of one specimen sighted near Maredumilly is deposited in the collection of the Natural History Museum of Osmania University (NHM.OU.REP.PV.19-2009), Hyderabad. Morphological and meristic studies (Table 1) were conducted in Department of Zoology, Osmania University, Hyderabad. Meristic counts and external observations of morphology were made using a dissecting microscope. Specimens 


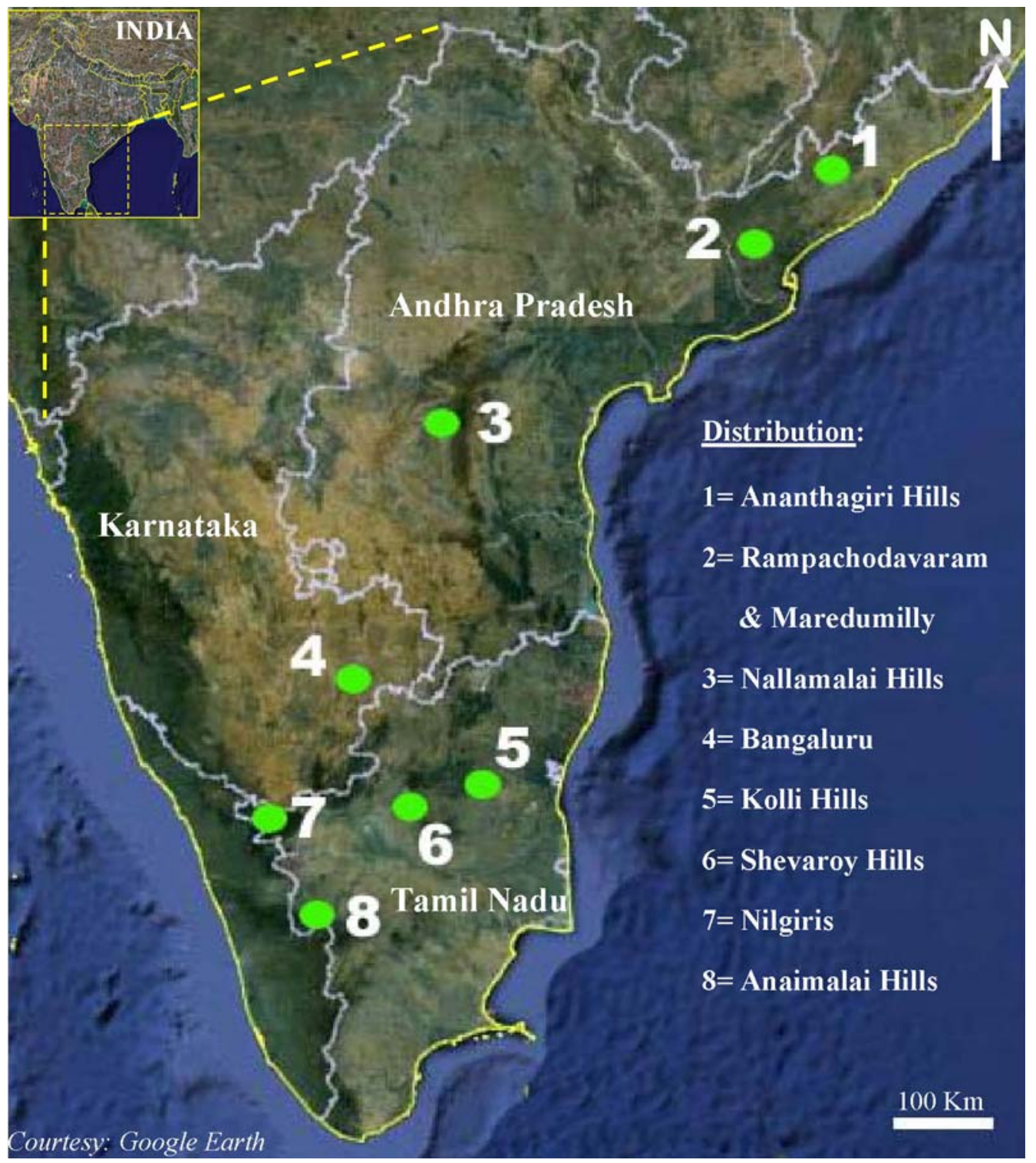

Image1. Satellite image showing a map depicting distribution of Hemiphyllodactylus aurantiacus (Beddome, 1870) in three Indian states (Andhra Pradesh, Karnataka and Tamil Nadu).

were identified based on the descriptions available in the literature (Smith 1935; Bauer \& Das 1999; Sharma 2002). Measurements were taken following Giri \& Bauer (2008) with Mitutoyo ${ }^{\mathrm{TM}}$ digital calipers (to the nearest $0.1 \mathrm{~mm}$ ): snout-vent length (SVL; from tip of snout to vent), trunk length (TRL; distance from axilla to groin measured from posterior edge of forelimb insertion to anterior edge of hindlimb insertion), body width (BW; maximum width of body), crus length (CL; from base of heel to knee); tail length (TL; from vent to tip of tail), tail width (TW; measured at widest point of tail); head length (HL; distance between retroarticular process of jaw and snout-tip), head width (HW; maximum width of head), head height $(\mathrm{HH}$; maximum height of head, from occiput to underside of jaws), forearm length (FL; from base of palm to elbow); orbital diameter (OD; greatest diameter of orbit), nares to eye distance (NE; distance between anteriormost point of eye and nostril), snout to eye distance (SE; distance between anteriormost point of eye and tip of snout), eye to ear distance (EE; distance from anterior edge of ear opening to posterior corner of eye), internarial distance (IN; distance between nares), interorbital distance (IO; shortest distance between left and right supraciliary scale rows).

\section{DESCRIPTION}

Hemiphyllodactylus aurantiacus (Beddome, 1870) is a small, slender, dorsoventrally compressed gecko with homogenous, granular scutellation (Malkmus et al. 2002). Head is oviform and longer than broad (Images 3 \& 5). Snout rounded, very convex and slightly shorter than the distance between eyes and ear-opening. Ear-opening very small and round. Body elongated, limbs short, fore limb measuring half the distance between axilla and groin, or rather less. Head covered with very minute granules. Rostral very small and almost pentagonal while mental is also very small and triangular. Nostril placed between rostral, first labial, and several granules. Labials very small, 10 upper and 10 lower, no chin-shields. Digits (Image 6) are relatively short and free, inner very small, rudimentary and only two large chevronshaped divided scansors beneath the distal part of the digits, 
Table 1. Morphometric and meristic data of Hemiphyllodactylus aurantiacus (Beddome, 1870) from Araku Valley, Ananthagiri Hills, Visakhapatnam District, Andhra Pradesh. (All morphometric measurements in $\mathrm{mm}$ and abbreviations explained under materials and methods. Asterisks refer to broken tail).

\begin{tabular}{lll}
\hline Character & $\begin{array}{l}\text { ZSI/FBS/V/1519* } \\
\text { (Female) }\end{array}$ & $\begin{array}{l}\text { ZSI/FBS/V/1520* } \\
\text { (Male) }\end{array}$ \\
\hline SVL & 30.8 & 32.2 \\
TRL & 15.0 & 17.1 \\
BW & 5.4 & 6.4 \\
CL & 4.2 & 4.4 \\
TL & 31.0 & 30.4 \\
TW & 3.8 & 3.9 \\
HL & 5.5 & 5.9 \\
HW & 5.7 & 5.9 \\
HH & 3.4 & 3.2 \\
FL & 2.8 & 3.0 \\
OD & 2.0 & 2.0 \\
NE & 2.1 & 2.7 \\
SE & 3.0 & 3.0 \\
EE & 2.8 & 2.8 \\
IN & 1.1 & 1.2 \\
IO & 3.6 & 3.7 \\
Scansors (divided, right/left): & \\
Digit I manus & $2 / 2$ & $2 / 2$ \\
Digit IV manus & $2 / 2$ & $2 / 2$ \\
Digit I pes & $2 / 2$ & $2 / 2$ \\
Digit IV pes & $3 / 3$ & \\
Labials (right/left): & & $10 / 10$ \\
Supralabials & $10 / 10$ & $10 / 10$ \\
Infralabials & $10 / 10$ & \\
\hline
\end{tabular}

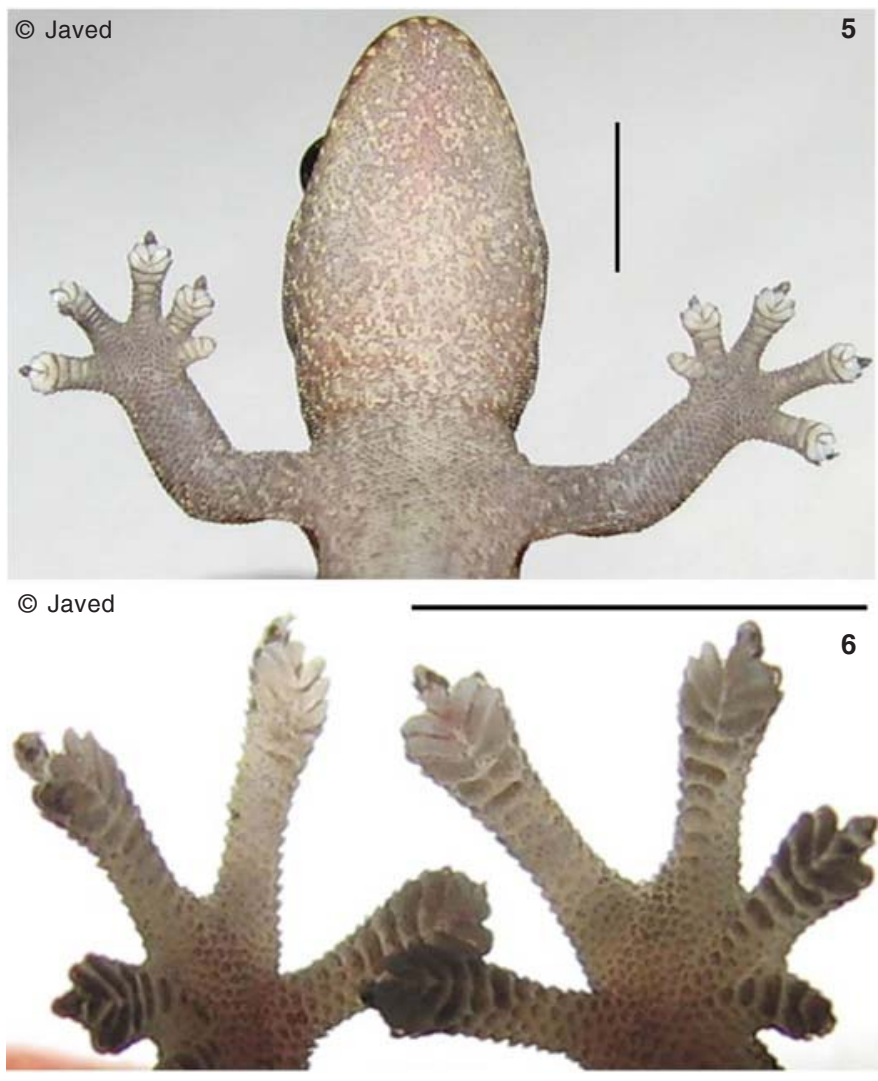

Images 5 \& 6 (Scale $5 \mathrm{~mm}$ )

5 - Ventral aspect of Hemiphyllodactylus aurantiacus (in life) male (ZSI/FBS/V/1520) head, axilla and digits of manus with scansors; 6 - Ventral aspect of Hemiphyllodactylus aurantiacus (in life) male (ZSI/FBS/V/1520) digits of pes with scansors.
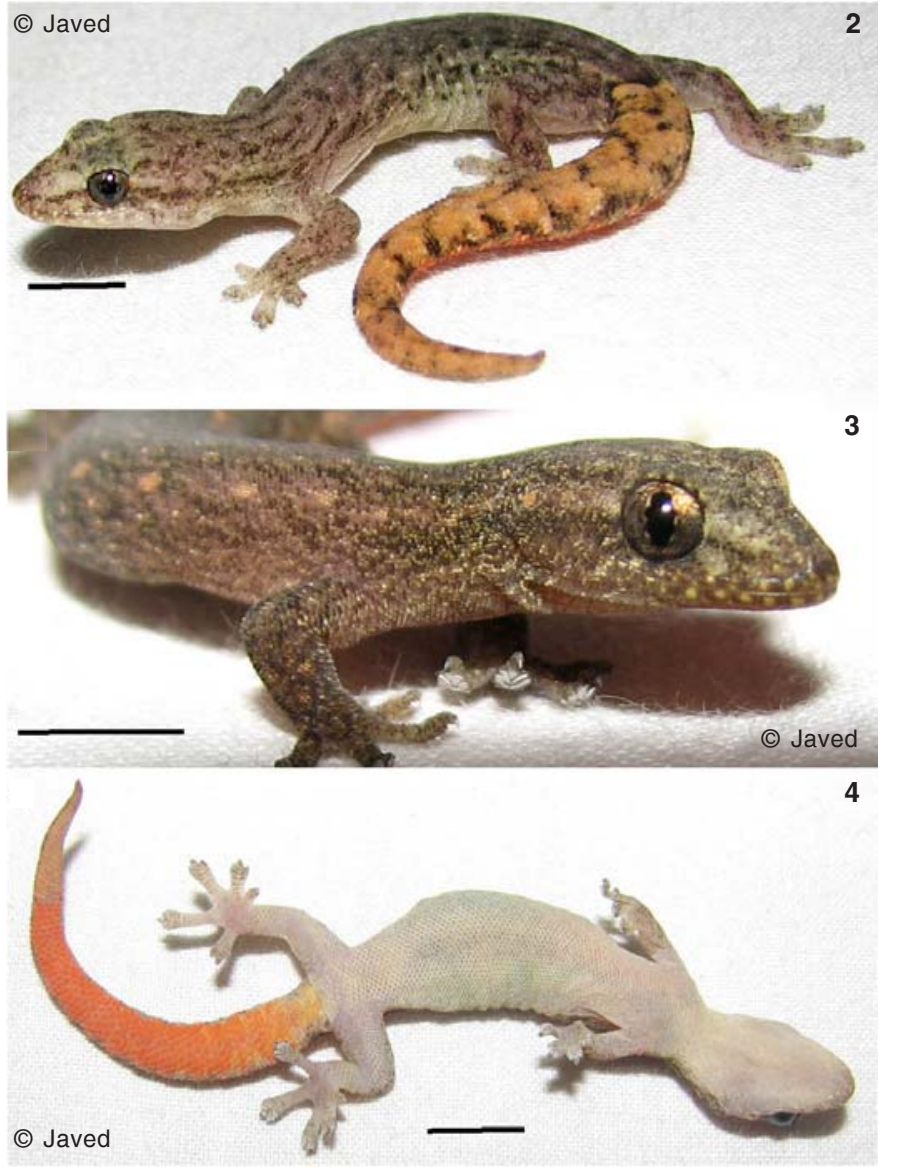

Images 2-4 (Scale $5 \mathrm{~mm}$ )

2 - Dorsolateral aspect of Hemiphyllodactylus aurantiacus (in life) female (ZSI/FBS/V/1519); 3 - Lateral aspect of Hemiphyllodactylus aurantiacus (in life) female (ZSI/FBS/V/ 1519) head region showing eye, ear opening and labials; 4 - Ventral aspect of Hemiphyllodactylus aurantiacus (in life) female (ZSI/FBS/V/1519).

followed by transverse undivided scansors, decreasing in width. In case of digits of pes (Images 5 \& 6) two divided scansors beneath first and second while three scansors beneath third, fourth and fifth. Back covered with very small granular scales, abdominal scales a little larger, flat and imbricate. Male possess five (left) / six (right) minute femoral pores and eight enlarged (in comparison with femoral pores) preanal pores. Postcloacal hemipeneal bulge distinct in males (Image 9). Both the sexes possess two equal sized postcloacal spurs (Image 9), but in females they are much smaller in size. Tail cylindrical, tapering, covered with small imbricate smooth scales, larger below (Images 8 \& 9).

Colouration: The colour pattern of Hemiphyllodactylus aurantiacus (Beddome, 1870) appears to be similar to that of Hemiphyllodactylus typus Bleeker, 1860 in most regards, but differs by showing a bolder pattern on body, comprising two series of thin, black stripes, a dark stripe under eye and distinct banded tail (Das 2002). The dorsal pattern of the specimens is however, bolder, tail pattern well defined, and the subcaudal colouration richer. The dorsum bears two series of thin black stripes. The first pair extends from the nasals, above the eyes and along the dorso-lateral margin of the animal's body to behind the forelimb insertion. A second dark, canthal stripe 


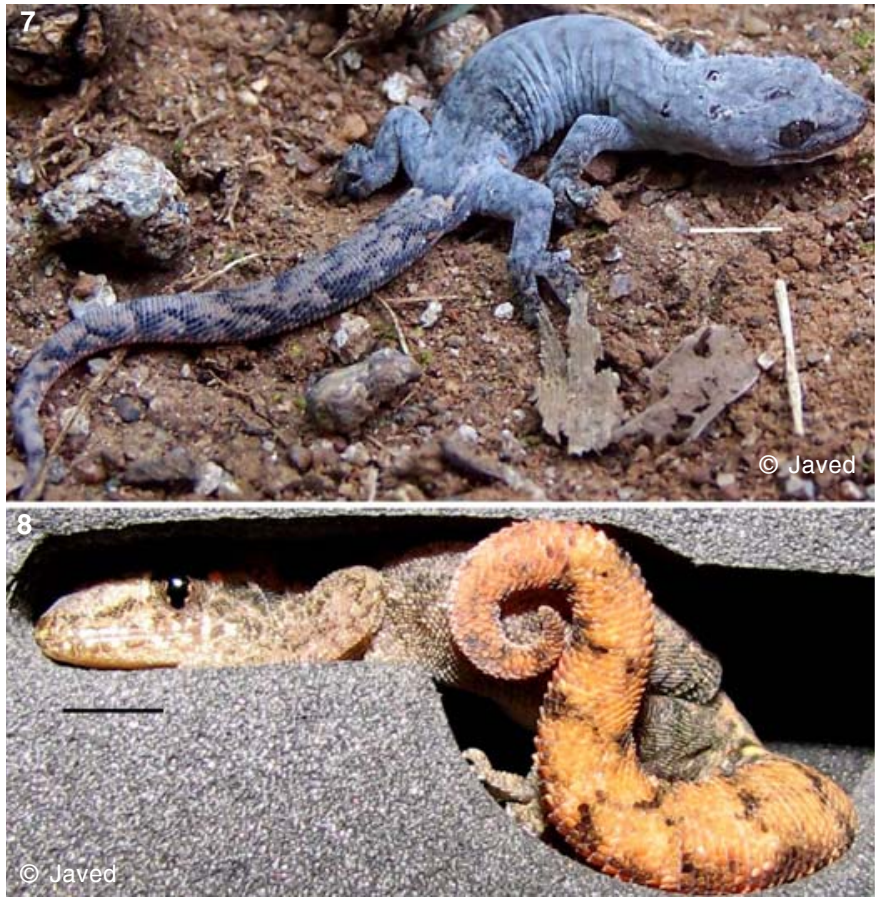

Images 7 \& 8 (Scale $5 \mathrm{~mm}$ )

7 - Dorsal aspect of Hemiphyllodactylus aurantiacus (in life) male photo voucher (NHM.OU.REP.PV.19-2009) showing peculiar colouration while sloughing-off skin; 8 -

Positioning of body under threat and dorsal aspect of tail of Hemiphyllodactylus aurantiacus (in life) male (ZSI/FBS/V/ 1520).

extends under each eye and continues to just behind the axilla. The base dorsal colouration is a light to mid-brown with darker dashes or broken transverse bars on the back. Small white clusters of scales are present on the flanks and along the dorsolateral body margin. The dorsum of the tail is boldly patterned with irregular dark bars, while the ventral side is orange-red (Images 2, 4, 8 \& 9), as noted by Bauer \& Das (1999). During the surveys, we found an individual undergoing ecdysis and displaying very peculiar colouration (Photo voucher-19, Image 7).

\section{HaBITS AND HaBItat}

Hemiphyllodactylus aurantiacus (Beddome, 1870) is a slow moving gecko species. On several occasions we have sighted this species feeding in a group of 4-6 individuals (of all age groups) on walls and floor of the buildings. This species found under stones in forested habitats and on walls of houses. It is nocturnal and active on relatively dark portion of walls, presumably to avoid competition with larger geckos (Das 2002). It has been seen with Hemidactylus sp. Hemidactylus cf. frenatus, Hemidactylus subtriedrus Jerdon, 1853 and Hemidactylus leschenaultii A.M.C. Duméril \& Bibron, 1836, and has been observed not to mingle with any of these species. It is timid in nature and very docile when handled. Some individuals escaped capturing by scuttling for some distance and then breaking into a rapid run. Gravid females, each with two eggs, were recorded in February. Das (2002) recorded egg production in January.

Hemiphyllodactylus aurantiacus (Beddome, 1870) is recorded from different locations and found occupying variety of habitats with hilly to rocky terrain, plenty of shade, humidity

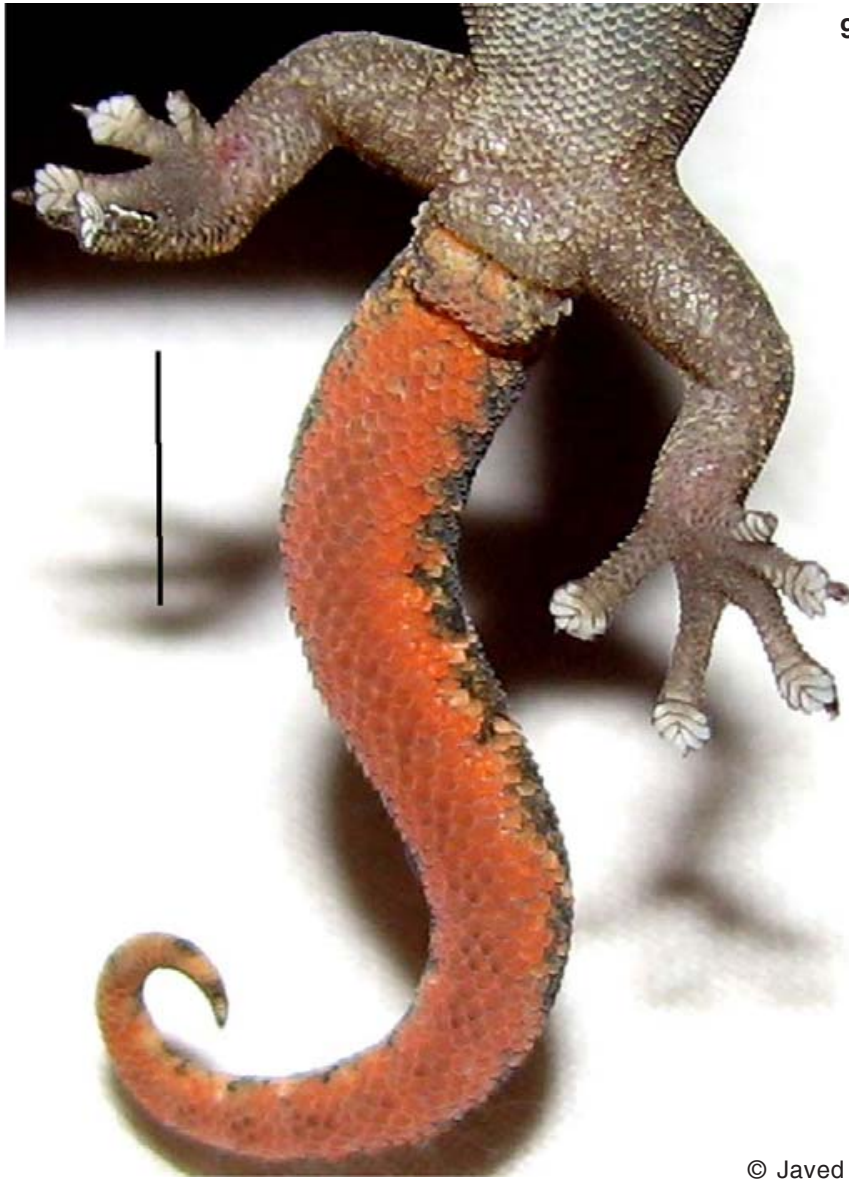

Image 9 (Scale $5 \mathrm{~mm}$ )

9 - Ventral aspect of Hemiphyllodactylus aurantiacus (in life) male (ZSI/FBS/V/1520) showing tail morphology, postcloacal spurs and hemipeneal bulge.

and also inside human habitations adjacent to forest patches. In Andhra Pradesh, this species occupies different forest types, from dry deciduous mixed scrub forest to semi moist deciduous forest cover.

\section{Distribution}

According to Smith (1935) Hemiphyllodactylus aurantiacus has been recorded from southern India (Nilgiri, Shevaroy and Anaimalai Hills in Tamil Nadu). Sanyal et al. (1993) reported it from Madhugulu and Araku Valley, Visakhapatnam District, Andhra Pradesh. After this it was recorded from Bangalore (now Bengaluru), Karnataka and Kolli Hills, Tamil Nadu (Daniels 1994; Daniels \& Kumar 1998). Later, Bauer \& Das (1999) recorded its presence from the type locality, Yercaud. Recently, we recorded its occurrence from Visakhapatnam District (Araku Valley, Ananthagiri and Tyda localities), East Godavari District (Rampachodavaram \& Maredumilly) and Prakasham District (Gundlabhrameshwarm Wildlife Sanctuarynear Temple locality) in Andhra Pradesh. Image 1 depicts the locations of the sites from where the species has been recorded from Andhra Pradesh along with earlier distribution in other states of India.

\section{StATUS AND THREATS}

Hemiphyllodactylus aurantiacus (Beddome, 1870) is 
treated as endemic to southern India and listed as Vulnerable (Molur \& Walker 1998). Very little is known about its ecology and major threats are restricted population, loss of habitat and human interference.

\section{Discussion}

Sanyal et al. (1993) reported Hemiphyllodactylus aurantiacus (Beddome, 1870) from Andhra Pradesh and since then there has been no record of this species from the state (Srinivasulu \& Das 2008). In the recent past it has not been reported from the Nallamalai Hills (Rao et al. 2005; Srinivasulu \& Das 2008). Bauer \& Das (1999) and Srinivasulu \& Das (2008) predicted its presence in other parts of Andhra Pradesh.

The Eastern Ghats of Andhra Pradesh are home to a varied fauna and some areas such as the Anathagiri and Nallamalai Hills, are home to a rich and diverse herpetofauna. Recent herpetofaunal studies carried out by WWF-India; EcoResearch and Monitoring Labs, Forest Department; Osmaina University (Rao et al. 2005; Srinivasulu \& Das 2008; Javed et al. 2009; this work) reveals this fact. The present study indicates that this species seems to be widely distributed and could be present in many other localities in Andhra Pradesh. Further exploration will probably reveal presence of Hemiphyllodactylus aurantiacus (Beddome, 1870) from other parts of Eastern Ghats in Andhra Pradesh, and its range may not be as limited as it appears now.

\section{References}

Bauer, A.M. \& I. Das (1999). The systematic status of the endemic South Indian gecko Hemidactylus aurantiacus (Beddome, 1870). Journal of South Asian Natural History 4(2): 213-218.

Daniels, R.J.R. (1994). Notes on a rare south Indian gecko, Hemiphyllodactylus typhus Beddome. Dactylus 2(4): 132-133.

Daniels, R.J.R. \& M.R. Kumar (1998). Amphibians and reptiles of Kolli Hills. Cobra 31: 3-5.

Das, I. (2002). A Photographic Guide to Snakes and other Reptiles of India. New Holland Publishers (UK) Ltd., London, 144pp.

Giri, V.B. \& A.M. Bauer (2008). A new ground-dwelling Hemidactylus (Squamata: Gekkonidae) from Maharashtra, with a key to the Hemidactylus of India. Zootaxa 1700: 21-34.

Malkmus, R., U. Manthey, G. Vogel, P. Hoffmann \& J. Kosuch (2002). Amphibians and Reptiles of Mount Kinabalu (North Borneo). A.R.G. Ganther Verlag, Rugell, 404pp.

Molur, S. \& S. Walker (eds.) (1998). Reptiles of India. Biodiversity Conservation Prioritisation Project (BCPP) India, Endangered Species Project - Conservation Assessment and Management Plan (C.A.M.P.) workshops. Zoo Outreach Organisation \& CBSG, India, Coimbatore, India, 175pp.

Sanyal, D.P., B.D. Gupta \& N.C. Gayen (1993). Reptilia, State Fauna Series 5. Fauna of Andhra Pradesh, Part I. Zoological Survey of India, Calcutta, 1-63pp.

Sharma, R.C. (2002). Fauna of India, Reptilia, Volume II, Sauria. Zoological Survey of India, Calcutta, 430pp.

Smith, M.A. (1935). Fauna of British India including Ceylon and Burma. Reptilia and Amphibia, Volume II, Sauria. Today and Tomorrow's Printers \& Publishers, New Delhi, Indian Reprint 1974, 440pp.

Srinivasulu, C. \& I. Das (2008). The Herpetofauna of Nallamalai Hills, Eastern Ghats, India: An Annotated Checklist, With Remarks on Nomenclature, Taxonomy, Habitat Use, Adaptive Types and Biogeography. Asiatic Herpetological Research 11: 110-131.

Rao, K.T., H.V. Ghate, A.M. Sudhakar, S.M.M. Javed \& I.S.R. Krishna (2005). Herpetofauna of Nallamalai Hills with eleven new records for the region including ten new records for Andhra Pradesh. Zoos' Print Journal 20(1): 1737-1740.

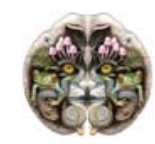

Author Details: S.M. MAQSOOd JAVEd is a Senior Field Research cum Education Officer, World Wide Fund for Nature- India, Andhra Pradesh State Office located at Hyderabad. His interest lies in biodiversity studies with special emphasis on arachnofauna and herpetofauna.

K. Thulsi RAO is Assistant Conservator of Forests, Nagarjunasagar-Srisailam Tiger Reserve. His current interest include biodiversity studies of the Nallamala Hills.

C. Srinivasulu is Assistant Professor and head of the research laboratory at Osmania University that focuses on biodiversity inventorying, conservation, ecology and animal taxonomy with special reference to Eastern Ghats and Godavari River basin in Andhra Pradesh.

FARIDA TAMPAL is State Director of the Andhra Pradesh State Office of World Wide Fund for Nature - India located at Hyderabad. She is interested in understanding the biodiversity of the Eastern Ghats with special emphasis on arachnofauna and herpetofauna.

Acknowledgements: The authors are very much thankful to Shri Hitesh Malhotra, IFS, Principal Chief Conservator of Forest (Wildlife) and Chief Wildlife Warden, Andhra Pradesh; Shri A.K. Nayak, IFS, Conservator of Forests \& Field Director, Nagarjunasagar Srisailam Tiger Reserve; Shri. R. Hampaiah, Chairman and Shri V.B. Ramana Murthy, Member Secretary, Andhra Pradesh Biodiversity Board for their constant support and encouragement. SMMJ and FT expresses gratitude to Shri Anil Kumar V. Epur, Chairman, WWF-AP State Committee, Hyderabad and Shri Ravi Singh, Secretary General \& CEO, WWF-India, New Delhi for constant support and encouragement. We express our thanks to Shri Swarnajit Sen, IPS (Retd.), Chairman, Shri B. Venkatesham, IAS, Managing Director and Shri P.V. Ramana Reddy, IFS, Executive Director, Andhra Pradesh Tourism Development Corporation, Hyderabad for constant support and permitting us to conduct biodiversity studies in APTDC Ecotourism sites. CS thanks Prof. T. Tirupathi Rao, Vice Chancellor, Osmania University and the Head, Department of Zoology, Osmania University, Hyderabad for encouragement and facilities. We thank Mr. R. Sreekar and Mr. M. Seetharamaruju of Department of Zoology, Osmania University assisted in taking morphological and morphometric data. Lastly, we would like to thank Mr. P.S.M. Srinivas, Manager Corporate for exploring new places and all the WWF-Staff of APSO, Hyderabad for their constant support and timely suggestions. 